\title{
Investigation of Influenza A, West Nile and Newcastle Disease Viruses in Birds from the Pantanal Wetlands of Mato Grosso, Brazil
}

qAuthor(s)
Pinto LB'
Ometto T"
Araújo J"
Thomazelli LM"
Seixas MM"
Barbosa CM"
Ramos DGS'
Melo ALT'
Pinho JB'
Durigon EL"
Aguiar DM'

Universidade Federal de Mato Grosso

" Universidade de São Paulo

\section{nail Address}

Corresponding author e-mail address Daniel Moura de Aguiar

Avenida Fernando Correa, 2367, Hospital Veterinário da UFMT

78060-900. Cuiabá, MT, Brazil

Phone: (65) 36158662

Email: danmoura@ufmt.br

\section{aKeywords}

Pantanal birds, Infectious Diseases, RT-PCR qRT-PCR, Virus.

\section{ABSTRACT}

The Pantanal is the world's largest wetland biome with a seasonal flood pulse that attracts a great diversity of birds, many of which are migratory. Birds can be natural reservoirs Influenza $A$, West Nile and Newcastle Disease viruses. However, the occurrence of carriers for these viruses in the Pantanal was not verified yet. The present study evaluated the occurrence of natural infection by Influenza A, WN and ND virus of birds in the municipality of Poconé, a subregion of the Pantanal in the state of Mato Grosso, Brazil. A total of 76 birds belonging to 11 orders and 20 families were captured using mist nets. The most representative order was Passeriformes, followed by the other nine orders, which included Columbiformes, Psittaciformes, Charadriiformes and Anseriformes. The most representative family was Thamnophilidae, with 16 individuals (21.0\%), followed by the family Tyrannidae with 10 individuals (7.6\%) and the family Furnariidae, with eight individuals (10.5\%). The bird species were identified, and cloacal and tracheal swab samples were collected. The samples were subjected to RNA extraction and tested for the presence of the three agents by real-time polymerase chain reaction (qRT-PCR). All the sampled birds were considered healthy, had no clinical sign of infection, and were tested negative for the three viruses. Based on our findings, we can conclude that Influenza, West Nile and Newcastle Disease viruses were absent from the samples in this region of the Pantanal wetlands during the period of this study.

\section{INTRODUCTION}

The Pantanal has a wide diversity of bird species and, compared to other similar floodplains around the world, it is considered the most diverse. Most of these species depend on multiple habitats to survive throughout the year, and the annual flood pulse of the Pantanal attracts many migratory birds, further contributing to the diversity of birds in this region (Pinho, 2005, Signor \& Pinho, 2011).

According to the first bird survey in the Brazilian Pantanal wetlands performed in 1986 by Brown Jr. (1986), and more recent surveys, the birds occurring most frequently in the Pantanal belong to the family Tyrannidae with 48 species, followed by the family Emberizidae with 21 species, including both resident and migratory birds (Nunes et al., 2008; Signor \& Pinho, 2011). Many of these birds, being they migratory, wild or domestic, are natural hosts and transmit various infectious viruses, such as Influenza A, West Nile and Newcastle Disease (Fernandes et al., 2010, Flores \& Weiblen, 2009).

The Avian Influenza virus belongs to the family Orthomyxoviridae and the genus Influenza $A$. The RNA of this virus comprises eight segments that encode several proteins, including hemagglutinin $(\mathrm{H})$ 
Pinto LB, Ometto T, Araújo J,

Thomazelli LM, Seixas MM, Barbosa CM,

Ramos DGS, Melo ALT, Pinho JB,

Durigon EL, Aguiar DM
Investigation of Influenza A, West Nile and Newcastle Disease Viruses in Birds from the Pantanal Wetlands of Mato Grosso, Brazil and neuraminidase $(\mathrm{N})$. These proteins are responsible for the characterization of the subtype viral strain of Influenza A. This virus, which is highly mutable and therefore presents high levels of virulence, has so far been isolated in birds, pigs, horses and mammals in general, including humans (Carneiro et al., 2009). Surveys of Influenza virus in bird specimens collected in the state of São Paulo, Brazil revealed high viral loads, emphasizing the need to monitor birds as reservoirs of Avian Influenza (Kawamoto et al., 2005). The first case of Avian Influenza Virus H11N9 isolated from migratory birds in South America was recently reported in the Amazon region (Araujo et al., 2014). However, the pathogenicity of those H11N9 subtypes was considered low.

The West Nile virus (WNV) belongs to the family Flaviviridae and the genus Flavivirus. This family also includes other very important pathogens such as Dengue virus and Yellow Fever virus (Flores \& Weiblen, 2009). There are two known WNV strains. The first was described in Africa in 1937, and present in Europe and Asia. The second strain circulates in North America since 1999; it was first described in New York and has subsequently spread throughout the United States, infecting wild and domestic birds, reptiles, mammals, and humans. The viral isolation case closest to Brazil was reported in Argentina in 2006, in an outbreak of equine neurologic disease. The ecological conditions of South and Central America, i.e., climate, vegetation and fauna, favor the introduction and maintenance of this virus in this region (Morales et al., 2006). Anti-WNV antibodies in horses have also been reported in the Pantanal region of Mato Grosso and its surroundings (Ometto et al., 2013, Pauvolid-Corrêa et al., 2011). In addition, the Brazilian Ministry of Health of Brazil recently reported a case of West Nile Virus (WNV) in the State of Piauí. This was the first detection of a human case of WNV infection in Brazil (Vieira et al., 2015).

The Newcastle Disease virus (NDV), which belongs to the family Paramyxoviridae and genus Avulavirus, has various pathogenic strains (Arns et al., 2007; Farkas et al., 2009; Fernandes et al., 2010). The history of Newcastle Disease began in 1926 with the description of a highly pathogenic disease in two geographical areas on opposite sides of the world, Newcastle-onTyne in England and the island of Java in Indonesia (Kraneveld, 1926; Doyle, 1927; Alexandre, 2001). NDV infections have been detected in at least 241 avian species, representing 27 of the 50 orders of the class (Alexander \& Manvell, 2004), and many serotypes have been isolated from asymptomatic wild aquatic birds (Alexander, 1995). Today this disease is distributed around the globe, since the lack of specific legislation on international trade in birds in the 90s enabled the worldwide dissemination of the virus (Farkas et al., 2009, Fernandes et al., 2010). Phylogenetic analysis has separated NDV into two sister clades, class I and II, which contain several genotypes each. The majority of reported virulent viruses belong to class II, while low virulence NDV, characteristic of wild birds, predominate in class I (Kim et al., 2008).

Considering the importance of the Pantanal wetlands of Mato Grosso as a region of agglomeration of resident and migratory birds, the aim of this study was to investigate the presence of Influenza, West Nile and Newcastle Disease viruses in birds collected in this region of Brazil.

\section{MATERIALS AND METHODS}

The study was carried out in the region of Porto Cercado, located in the municipality of Poconé, state of Mato Grosso (Figure.1). The studied area contains four forest types known regionally as Cambarazal, Landizal, Pombeiro and Cordilheiras. These phytophysiognomies are forests seasonally flooded from January to June, except for Cordilheiras, which is flood-free throughout the year. The climate is characterized by a pronounced dry season from May to September and a wet season from October to April, with an average rainfall of 1400 $\mathrm{mm}$ in the rainy season, with maximum rainfall in January and minimum in July (Nunes \& Junk, 2004).

The birds were captured in July and November, 2013, and February, 2014. Captures were carried out using ten $10 \mathrm{~m}$ long, $2.75 \mathrm{~m}$ tall mist nets ( $36 \mathrm{~mm}$ mesh) set up consecutively in three sampling points. The collection campaign covered the three seasonal cycles of the Pantanal, i.e., the flood, ebb and dry phases. The nets were left open to capture specimens only in the morning, from 06:00 to 10:00h. Species were identified based on the field guide of Qwynne et al. (2010), and, after completing the capture and sample collection processes, the birds were released. The sampling effort involved 1200 mist net/hours (Signor \& Pinho, 2011) and encompassed a total area of $100 \mathrm{~m}$ at each collection point.

Secretions of the cloaca and orotracheal mucosa of the captured birds were sampled using sterile disposable swabs. Samples were stored in $2 \mathrm{~mL}$ cryotubes in transportation media containing antifungals, antibiotics, and glycerol, according to the protocol 


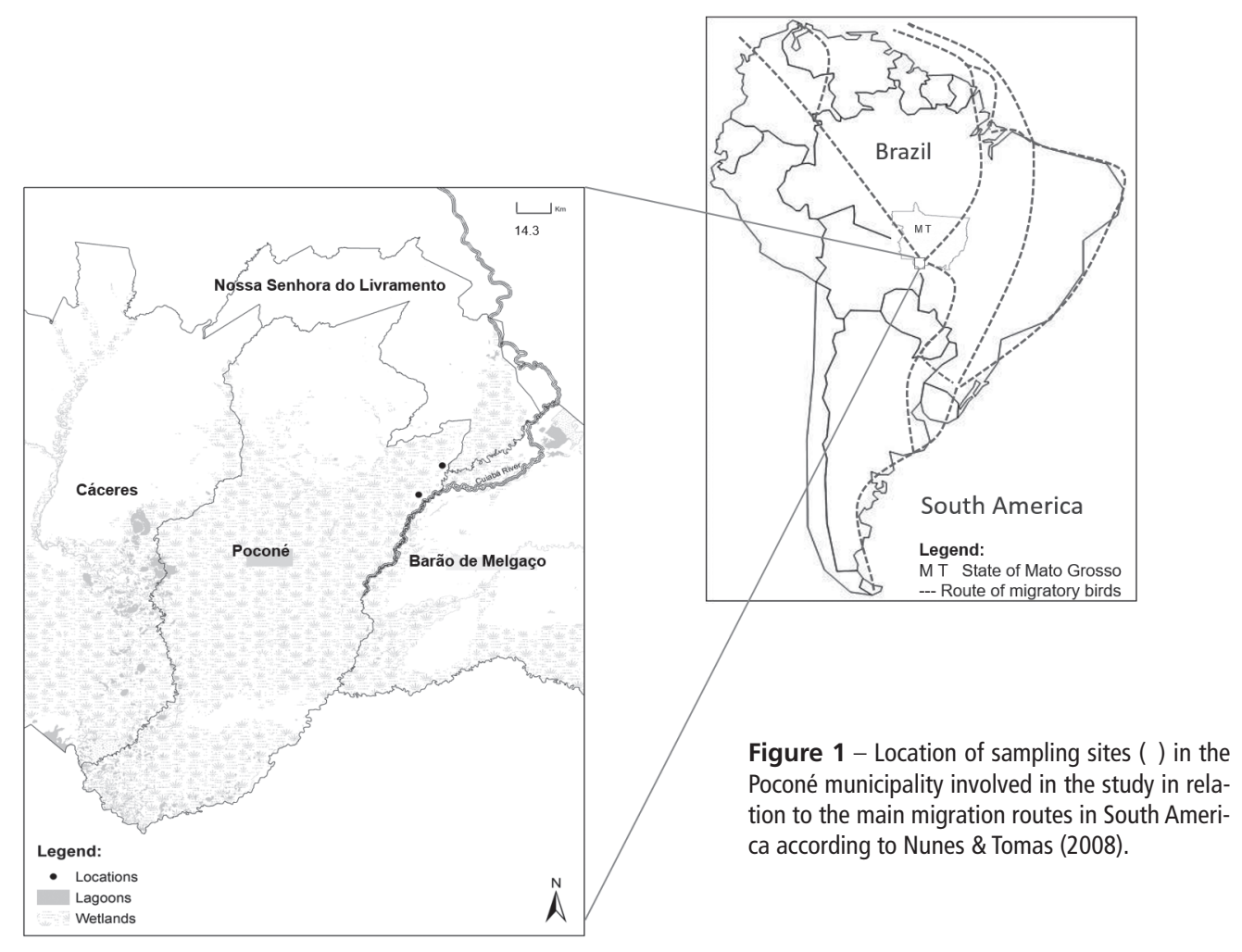

described in the Manual on Animal Influenza Diagnosis and Surveillance of the World Health Organization (Webster et al., 2002). The duly identified cryotubes were immediately frozen in liquid nitrogen at $-196^{\circ} \mathrm{C}$ until the moment of analysis.

Cloacal and orotracheal samples from each individual bird were pooled. The genetic material in each pool was extracted using a semi-automated MagMAX'M Express-96 Pathogen RNA/DNA kit (5X) (Ambion, Inc., Austin, TX, USA), according to the protocol described by Ometto et al. (2013). The RNA sample extracted from each pool was analyzed by OneStep Quantitative Real-Time PCR (qRT-PCR) in an ABI 7300 Real-Time PCR System $\AA$ (Applied Biosystems, Foster City, CA, USA). The CDNA was synthesized from the extracted viral RNA, which amplifies the genetic material in a single step using specific probes and primers for each agent.

A TaqMan AIV-M Matrix Reagents kit (Applied Biosystems) was used for the detection of Influenza virus, using specific primers for the matrix gene (Curd et al., 2011). For the detection of WNV, specific primers for Gene E, SEQ1F (GCGATCTCTCCACCAAAGCT) and SEQ1R (TGGGTCAGCACGTTTGTCAT) were applied with the SEQ1M1 [FAM]-CCATGGGAGAAGCTCACA [NFQ] probe (Ometto et al., 2013). Lastly, to detect both classes of NDV, a specific class I NDV pair of primers, forward for the matrix gene $M+4100 F$ (AGTGATGTGCTCGGACCTTC) and reverse for M-4220R (CCTGAGGAGAGGCATTTGCTA), covering $120 \mathrm{pb}$, were applied with an M4169 [FAM] TTCTCTAGCAGTGGGACAGCCTGC [MGB] probe (Wise et al., 2004); and class II NDV with same cycling conditions, allowing a multiplex format, whereupon the polymerase gene $L+8738$ sense primer (TGTTGAAAAGAAGCTGCTAGGC) and reverse L-8847 (TGGACCATGAAGAGTGGAACC), were applied with an L8762 [TET] TGCCTGGTCACACAAGATCCGCCG [MGB] probe (Kim et al., 2008).

The samples that showed an amplification curve in the qRT-PCR for any of the three viruses under study were then subjected to conventional RT-PCR. Samples that had real-time PCR amplification for Influenza virus were retested using the conventional PCR method on another region of interest of the matrix gene, using specific forward M52CF (CTTCTAACCGAGGTCGAAACG) and reverse M253R (AGGGCATTTTGGACAAAKCGTCTA) primers that amplify approximately 245 bp. Samples amplified by one-step RT-PCR are considered positive only after amplification by standard RT-PCR and confirmation by sequence analysis.

The resulting amplifications were subjected to an electrophoretic run in 1\% agarose gel and examined 
Pinto LB, Ometto T, Araújo J,

Thomazelli LM, Seixas MM, Barbosa CM,

Ramos DGS, Melo ALT, Pinho JB,

Durigon EL, Aguiar DM
Investigation of Influenza A, West Nile and Newcastle Disease Viruses in Birds from the Pantanal Wetlands of Mato Grosso, Brazil using a transilluminator under UV light (Webster et al., 2002). The products of the conventional RT-PCR amplification were purified according to the protocol of Applied Biosystems, using ExoSAP-IT (GE) reagent on $5 \mu$ of cDNA sample, followed by purification using BigDye $^{\circledR}$ XTerminator reagent (Applied Biosystems). Lastly, the purified samples were subjected to direct double-stranded sequencing using a BigDye Terminator Cycle Sequencing Ready Reaction kit and AmpliTaq DNA polymerase kit (Applied Biosystems) (Thomazelli et al., 2012). The samples were sequenced in an ABI PRISM 3100 Genetic Analyzer and the resulting sequences were aligned with other corresponding sequences available in GenBank, using the NCBI Nucleotide BLAST Search program (Altschul et al., 1990).

All the above described laboratory procedures were performed in the Level $3^{+}$Biosafety Laboratory $\left(\mathrm{BSL}^{+}\right)$of the Institute of Biomedical Sciences II at the University of São Paulo (USP). This project was registered on March 23, 2013 in Brazil's Biodiversity Authorization and Information System - SISBIO, under No. 10698-3, and was granted a permanent license to collect zoological material. The project is also filed at the Ethics Committee on Animal Use (CEUA), under No. 23108.041148/13-0, in accordance with the ethical principles of animal experimentation adopted by the National Council for the Control of Animal Experimentation (CONCEA).

\section{RESULTS}

Seventy-six endemic, migratory, domestic and wild birds were recorded, distributed among 11 orders and 20 families. The most representative order was Passeriformes (10 families, representing $50 \%$ of the total), followed by the other nine orders, which included Columbiformes, Psittaciformes, Charadriiformes, and Anseriformes, each represented by only one family. The most representative family was Thamnophilidae, with 16 individuals $(21.0 \%)$, followed by the family Tyrannidae with 10 individuals (7.6\%) and the family Furnariidae, with eight individuals (10.5\%) (Table 1).

No amplification curves were observed in the qRTPCR for either WNV or NDV. In the case of Influenza A virus, 14 samples showed an amplification curve in the initial qRT-PCR results. Then, using the conventional PCR method, 10 samples presented amplicons of approximately $245 \mathrm{bp}$. The amplified suspected samples were sequenced and analyzed in the database. However, none of the samples presented a sequence similar to that of Influenza A virus.

\section{DISCUSSION}

Despite the considerable number and diversity of bird species sampled in this study, none was tested positive for the target agents. According to Steininger et al. (2002), the most suitable tests for effectively diagnosing avian viral diseases, including avian Influenza, WNV and NDV, are RT-PCR and qRT-PCR owing to their high sensitivity and specificity. Based on these data, we analyzed the samples from the captured birds for the three viruses, using molecular methods. Nguyen et al. (2013) found that the use of multiplex qPCR can lead low detection sensitivity, which is why they tested the three viruses separately.

Pauvolid-Correa et al. (2011) described the Pantanal as a favorable location for studies on infectious diseases in birds, considering that natural infection foci have already been described in wetlands around the world. Moreover, the abundant movement of migratory birds in Brazilian Pantanal wetlands explains the recent detection of arboviral infection in humans, horses and reptiles in the region, and of antibodies against WNV in horses. On the other hand, crocodilians captured in the Pantanal, coexisting with several species of water birds, tested negative for WNV (Pauvolid-Corrêa et al., 2011), which is consistent with the findings of this study. Ometto et al. (2013), who also evaluated birds in the same region, did not detect any positivity for WNV. Negative results in birds and crocodilians, coupled with the serological detection of antibodies in horses, reinforces the need for further studies and intensive surveillance of WNV in the Pantanal region.

In this study, none of the birds collected in the Pantanal was tested positive for NDV. On the other hand, Demetrio (2002) reported the detection of NDV in wild birds in the state of São Paulo by RT-PCR, and emphasized the significant sensitivity of this test and the importance of monitoring Newcastle Disease in wild birds in Brazil. The negative results found in this study for Influenza viruses are similar to those reported by Buscaglia (2012), who captured 157 birds in Argentina, all of which were tested negative for the presence of the avian influenza virus. On the other hand, Kawamoto et al. (2005) and Soares et al. (2005) detected the presence of Influenza $A$ viruses in wild and migratory birds in the state of São Paulo. The first subtype H11N9 isolated from migratory birds collected in the Amazon region was recently reported, and was found to present a very high similarity with viral subtypes described in North 
Pinto LB, Ometto T, Araújo J,

Thomazelli LM, Seixas MM, Barbosa CM,

Ramos DGS, Melo ALT, Pinho JB,

Durigon EL, Aguiar DM

\section{Investigation of Influenza A, West Nile and Newcastle Disease Viruses in Birds from the Pantanal Wetlands of Mato Grosso, Brazil}

Table 1 - Order, Family and species of birds collected in the Pantanal region of Poconé, that resulted negative for Influenza A, West Nile and Newcasttle viruses.

\begin{tabular}{|c|c|c|c|}
\hline Order & Family & Species & Collected \\
\hline \multirow{30}{*}{ Passeriformes } & \multirow{2}{*}{ Emberizidae } & Arremon flavirostris & 1 \\
\hline & & Paroaria capitata & 2 \\
\hline & \multirow{7}{*}{ Tyrannidae } & Basileuterus flaveolus & 3 \\
\hline & & Camptostoma obsoletum & 1 \\
\hline & & Hemitriccus striaticollis & 1 \\
\hline & & Inezia inornata & 1 \\
\hline & & Myiarchus ferox & 2 \\
\hline & & Platyrinchus mystaceus & 1 \\
\hline & & sp. & 1 \\
\hline & \multirow{2}{*}{ Troglodytidae } & Campylorhynchus turdinus & 2 \\
\hline & & Pheugopedius genibarbis & 1 \\
\hline & \multirow{7}{*}{ Thamnophilidae } & Cercomacra melanaria & 4 \\
\hline & & Herpsilochmus longirostris & 1 \\
\hline & & Thamnophilus doliatus & 1 \\
\hline & & Thamnophilus pelzelni & 1 \\
\hline & & Taraba major & 3 \\
\hline & & Hypocnemoides maculicauda & 3 \\
\hline & & Myrmotherula axillaris & 3 \\
\hline & \multirow{3}{*}{ Furnariidae } & Cranioleuca vulpina & 5 \\
\hline & & Synallaxis albilora & 1 \\
\hline & & Furnarius leucopus & 2 \\
\hline & \multirow{3}{*}{ Thraupidae } & Lanio penicillata & 2 \\
\hline & & Ramphocelus carbo & 1 \\
\hline & & Tachyphonus luctuosus & 2 \\
\hline & Pipridae & Pipra filicauda & 1 \\
\hline & Rhynchocyclidae & Poecilotriccus latirostris & 3 \\
\hline & \multirow{3}{*}{ Dendrocolaptidae } & Sittasomus griseicapillus & 2 \\
\hline & & Xiphorhynchus guttatus & 1 \\
\hline & & Xiphorhynchus picus & 2 \\
\hline & Turdidae & Turdus leucomelas & 1 \\
\hline Apodiformes & Trochilidae & Amazilia fimbriata & 1 \\
\hline \multirow{2}{*}{ Psittaciformes } & \multirow{2}{*}{ Psittacidae } & Amazona aestiva & 1 \\
\hline & & Psittacara leucophthalmus & 1 \\
\hline Charadriiformes & Charadriidae & Vanellus chilensis & 1 \\
\hline Anseriformes & Anatidae & Amazonetta brasiliensis & 2 \\
\hline Strigiformes & Strigidae & Athene cunicularia & 1 \\
\hline \multirow{2}{*}{ Accipitriformes } & \multirow{2}{*}{ Accipitridae } & Buteogallus urubitinga & 1 \\
\hline & & Spizaetus melanoleucus & 1 \\
\hline \multirow{2}{*}{ Columbiformes } & \multirow{2}{*}{ Columbidae } & Columbina $s p$ & 1 \\
\hline & & Leptotila rufaxilla & 3 \\
\hline Galbuliformes & Galbulidae & Galbula ruficauda & 1 \\
\hline Galliformes & Phasianidae & Galus galus & 6 \\
\hline Rheiformes & Rheidae & Rhea americana & 1 \\
\hline
\end{tabular}

America (Araujo et al., 2014). Therefore, the lack of detection of the viruses in the birds of present study may be associated with the captured species, which were mostly resident species with terrestrial habits. Cui et al. (2011) stated that only aquatic birds of the orders Charadriiformes and Anseriformes are natural hosts of Influenza virus, and in our study, these two orders of aquatic birds accounted for only $18 \%$ of the total sample.
Based on the findings of this study, it can be concluded that there was no evidence of the circulation of Influenza $A, W N$, or ND viruses in the birds studied between 2013 and 2014 in the northern Pantanal wetlands. Despite the low incidence of NDV and Influenza virus in Brazil, it is essential to monitor these virus in scientific studies because Brazil is one of the world's largest exporters of poultry products. In North America and most European countries, the Avian 
Pinto LB, Ometto T, Araújo J,

Thomazelli LM, Seixas MM, Barbosa CM,

Ramos DGS, Melo ALT, Pinho JB,

Durigon EL, Aguiar DM
Investigation of Influenza A, West Nile and Newcastle Disease Viruses in Birds from the Pantanal Wetlands of Mato Grosso, Brazil
Influenza virus is constantly monitored in wild birds, whereas there still is a significant gap in the knowledge on those viruses in wild birds in South America, and particularly in Brazil (Araujo et al., 2014).

In summary, this study highlights the need for further in-depth research involving the continuous monitoring of the birds in the Pantanal region, and in particular, to expand sampling during every season in order to include a wider variety of avian species, which are considered potential reservoirs of infectious diseases. The purpose of such an epidemiological strategy is to minimize possible risks to public health resulting from the local introduction of these viruses.

\section{ACKNOWLEDGMENTS}

We gratefully acknowledge the following Brazilian research funding entities: CAPES (Federal Agency for the Support and Improvement of Higher Education) for a scholarship granted to Leticia B. Pinto, FAPESP (São Paulo Research Foundation) for the scholarships granted to Tatiana Ometto and Jansen de Araujo, CNPq (National Council for Scientific and Technological Development) for the Scientific Productivity Grant awarded to Daniel M. Aguiar, and Estância Ecológica SESC Pantanal for logistical support.

\section{FUNDING}

This work was funded by the National Institute of Wetland Sciences and Technology and São Paulo Research Foundation - FAPESP (2013/05485-2; 2011/13821-7, and 2009/05994-9).

\section{REFERENCES}

Alexander DJ. The epidemiology and control of avian influenza and Newcastle Disease. Journal of Comparative Pathology 1995;112:105126.

Alexandre DJ. Newcastle disease. British Science 2001;42:5-22.

Alexander DJ, Manvell RJ. Heat inactivation of Newcastle Disease virus (strain Herts 33/56) in artificially infected chicken meat homogenate. Avian Pathology 2004;3(2):222-225

Altschul SF, Gish W, Miller W, Myers EW, Lipman DJ. Basic local alignment search tool. Journal of Molecular Biology 1990;215:403-410.

Araujo J, Azevedo Jr SM, Gaidet N, Hurtado RF, Walker D, Thomazelli LM, et al. Avian Influenza Virus (H11N9) in migratory shorebirds wintering in the Amazon region, Brazil. PLoS ONE 2014;9(10):e110141.

Arns C, Spilki WFR, Almeida RS. Paramyxoviridae. In. Flores EF, editor. Virologia veterinária. Santa Maria: Universidade Federal de Santa Maria; 2007. p.888.

Brown Jr. Zoogeografia da região do Pantanal Mato-Grossense. Anais do Simpósio Sobre Recursos Naturais do Pantanal Mato-Grossense; 1986; Corumbá, Mato Grosso do Sul. Brasil. p.137-178.
Buscaglia C. A survey for avian influenza from gulls on the coasts of the District of Pinamar and the Lagoon Salada Grande, General Madariaga, Argentina. Avian Diseases 2012;56(4 Suppl):1017-1020.

Carneiro M, Trench FJP, Waib LF, Pedro FL, Motta F. Influenza H1N1 2009 Revisão da Primeira Pandemia do Século XXI. Revista da AMRIGS 2010;54(2):206-13

Cui P, Hou Y, Xing Z, He Y, Li T, Guo S, et al. Bird migration and risk for H5N1 transmission in Qinghai Lake, China. Vector-Borne and Zoonotic Diseases 2011;11(5):567-76.

Curd E, Pollinger J, Toffelmier E, Smith T. Rapid influenza A detection and quantitation in birds using a one-step real-time reverse transcriptase PCR and High Resolution Melting. Journal of Virological Methods 2011;176(1-2):125-130.

Demétrio C. Levantamento sorológico e pesquisa do vírus da doença de Newcastle em irerês migratórios, Dendrocygna viduata (Anseriformes: Anatidae), na cidade de São Paulo, Brasil [dissertação]. São Paulo (SP): Universidade de São Paulo; 2002.

Doyle TM. A hitherto unrecorded disease of fowls due to a filterpassing virus. Journal of Comparative Pathology and Therapeutics 1927;40:144-169.

Farkas T, Szekely E, Bela S, Kiss I. Real-Time PCR-Based pathotyping of Newcastle Disease Virus by use of taqman minor groove binder probes. Journal of Clinical Microbiology 2009;47(7):2114-2123.

Fernandes LMB, Silva PS, Ramos I, Sales TS, Herval EFG, Batinga TB, et al. Soroepidemiologia da Doença de Newcastle em planteis de avestruz do Estado da Bahia e de São Paulo. Ciência Rural 2010;40(1):135-140.

Flores EF, Weiblen R. West Nile vírus. Ciência Rural 2009;39(2):604-612.

Qwynne J A, Ridgely R S, Tudor G, Argel M. Wildlife conservation society birds of Brazil - the Pantanal and Cerrado of Central Brazil. New York: Comstock Publishing; 2010

Kawamoto AHN, Mancini DAP, Pereira LE, Cianciarullo AM, Cruz AS, Dias $A L F$, et al. Investigation of Influenza in migrating birds, the primordial reservoir and transmitters of Influenza in Brazil. Brazilian Journal Microbiology 2005;36(1):88-93

Kim LM, Suarez DL, Afonso CL. Detection of a broad range of class I and II Newcastle disease viruses using a multiplex real-time reverse transcription polymerase chain reaction assay. Journal of Veterinary Diagnostic Investigation 2008;20:414-425.

Kraneveld FC. A poultry disease in the Dutch East Indies. Nederlands Indische Bladen Voor Diergeneeskunde 1926;38:448-450.

Morales MA, Barrandeguy M, Fabbri C, Garcia JB, Vissani A, Trono K, et al. West Nile virus isolation from equines in Argentina, 2006. Emerging Infectious Disease 2006;12(10):1559-1561.

Nguyen TT, Kwon HJ, Kim H, Hong SM, Seong WJ, Jang JW, et al. Multiplex nested RT-PCR for Detecting Avian Influenza Virus, Infectious Bronchitis Virus and Newcastle Disease Virus. Journal of Virological Methods 2013;188:41-46.

Nunes AP, Tomas WM. Aves migratórias e nomades ocorrentes no Pantanal. Corumbá: EMBRAPA; 2008.

Nunes AP, Da Silva PA, Tomas WA. Novos registros de aves para o Pantanal, Brasil. Revista Brasileira de Ornitologia 2008;16(2):160-164.

Ometto T, Durigon EL, Araujo J, Aprelon R, Aguiar DM, Cavalcante GT, et al. West Nile Virus Surveillance, Brazil 2008-2010. Transactions of the Royal Society of Tropical Medicine and Hygiene 2013;107(11):723730 
Pauvolid-Corrêa AM, Morales A, Levis S, Figueiredo LTM, Couto-Lima M, Campos Z, et al. Neutralising antibodies for West Nile virus in horses from Brazilian Pantanal. Memórias do Instituto Oswaldo Cruz 2011;106(4):467-474.

Pinho JB. Riqueza de espécies, padrões de migração e biologia reprodutiva de aves em quatro ambientes florestais do Pantanal de Poconé, MT [thesis]. Belo Horizonte (MG): Universidade Federal de Minas Gerais; 2005.

Signor CA, Pinho JB. Spatial diversity patterns of birds in a vegetation mosaic of the Pantanal, Mato Grosso, Brazil. Zoologia 2011;28(6):725738 .

Soares PBM, Demétrio C, Sanfilippo L, Kawanoto AHN, Brentano L, Durigon EL. Standardization of a duplex RT-PCR for the detection of Influenza A and Newcastle disease viruses in migratory birds. Journal of Virological Methods 2005;123(2):125-130.

Steininger C, Kundi M, Aberle SW, Aberle JH, Popow-Kraupp T. Effectiveness of reverse transcription-PCR, virus isolation, and enzyme-linked immunosorbent assay for diagnosis of Influenza A virus infection in different age groups. Journal of Clinical Microbiology 2002;40(6):20512056.

Thomazelli LM, Araújo J, Ferreira C, Huratado R, Oliveira DB, Ometto T, et al. Molecular Surveillance of Newcastle Disease Virus in domestic and wild birds on the Northeastern Coast and Amazon biome of Brazil. Brazilian Journal of Poultry Science 2012;14(1):1-7.

Vieira MA, Romano AP, Borba AS, Silva EV, Chiang JO, Eulálio KD, et al. West Nile Virus encephalitis: the first human case recorded in Brazil. American Journal of Tropical Medicine and Hygiene 2015;93(2):377379 .

Webster R, Cox N, Stohr K. WHO - Manual on animal influenza diagnosis and Surveillance Global Influenza Programme. Geneva: The World Health Organization; 2002.

Wise MG, Suarez DL, Seal BS, Pedersen JC, Senne DA, King DJ, et al. Development of a real-time reverse-transcription PCR for detection of Newcastle Disease Virus RNA in clinical samples. Journal of Clinical Microbiology 2004;42(1):329-338. 
